\title{
METHODICAL APPROACH TO ASSESSING THE STATE OF COMPREHENSIVE ECONOMIC SECURITY OF HIGHER EDUCATION INSTITUTIONS
}

\section{Mykhailo Laptiev ${ }^{1}$, Oleksandr Zakharov ${ }^{2}$}

${ }^{1}$ Ph.D. (Economics), Associate Professor of the Financial and Economic Security Management Department, KROK University, Kyiv, Ukraine, e-mail: michael.laptev@krok.edu.ua, ORCID: https://orcid.org/00000002-3537-6345

${ }^{2}$ Ph.D. (Economics), Professor, Director of the Institute of Security Management, KROK University, Kyiv, Ukraine,e-mail: zaharov@krok.edu.ua, ORCID: https://orcid.org/0000-0001-6429-8887

Given the need to diagnose the state of comprehensive economic security of higher education institution in the process of European integration, a methodological way was proposed, which involves conducting assessments at the following stages (Fig. 1).

1) analysis of the composition and structure of the economic security system of higher education institutions;

2) assessment of the peculiarities of the functioning of the system from the standpoint of economic security;

3) study of sources of informational and analytical support of economic security;

4) determination of indicators for assessing the state of comprehensive economic security of higher education institutions (Fig. 2);

5) formation of an integrated indicator for assessing the state of comprehensive economic security of higher education institutions and its characteristics;

6) analysis of the interaction of the system with internal and external environment.

With the concept of "methodological approach to assessing the state of comprehensive economic security of higher education institution" the author proposes to understand a set of general and specific methods of diagnosing the state of comprehensive economic security, taking into account the specifics of higher education institutions.

At the first stage, the analysis of composition and structure of the complex economic security of higher education institution is made by comparing the existing model on a particular higher education institution model. The discrepancies found in the process of analysis are proposed to be marked as threats that affect the state of integrated economic security of higher education institution and to be assessed in accordance with the threat assessment methodology.

At the third stage, the sources of informational and analytical support of economic security of higher education institution are studied, which are external (state and departmental) and internal documents. 


\section{Stage I}

- analysis of the composition and structure of the economic security system of higher education institutions

\section{Stage II}

- assessment of the peculiarities of the system from the standpoint of economic security

\section{Stage III}

- study of sources of information and analytical support of economic security

\section{Stage IV}

- determination of indicators for assessing the state of comprehensive economic security of higher education institutions

\section{Stage V}

- formation of an integrated indicator for assessing the state of comprehensive economic security of higher education institutions and its characteristics

\section{Stage VI}

- analysis of the interaction of the system with the internal and external environment

\section{Fig. 1. The main stages of assessing the state of comprehensive economic security of higher education}

Source: developed by the authors

At the fourth stage, indicators for assessing the state of comprehensive economic security of higher education institutions are determined by grouping them depending on the resources used for granting comprehensive economic security of free economic education.

The method of assessing the state of integrated economic security of higher education institution is a binomial model for assessing the impact of threats on the internal resources of economic security of higher education institution.

The main indicators, the calculation of which is provided in accordance with the proposed method, are presented in Fig. 2. 
Indicators for evaluating the information support of free economic zones

Indicators for assessing the organizational and managerial support of free economic zones

Indicators for assessing the financial support of free economic zones

Indicators for assessing the administrative support of free economic zones

Indicators for assessing the corporate security of free economic zones

Indicators for assessing the state of economic security

Indicators for assessing the innovative provision of free economic zones

Fig. 2. Indicators for assessing the integrated economic security of higher education institutions

Source: developed by the authors

Indicators for assessing staffing of higher education institution from the standpoint of economic security are given in table. 1.

Table 1. Indicators for assessing staffing of higher education institution from the standpoint of economic security

\begin{tabular}{|c|c|c|c|}
\hline Indicators & Designation & True (1) & False (0) \\
\hline $\begin{array}{l}\text { The staffing schedule provides presence of a } \\
\text { structural unit or a specialist in ensuring the } \\
\text { quality of educational services }\end{array}$ & $\mathrm{K}^{1}{ }_{1}$ & & \\
\hline $\begin{array}{l}\text { Staffing meets the licensing requirements for } \\
\text { all specialties and licenses obtained for them }\end{array}$ & $\mathrm{K}_{2}^{1}$ & & \\
\hline $\begin{array}{l}\text { The functions of specialists in ensuring the } \\
\text { quality of educational services are controlled } \\
\text { by the economic security department of the } \\
\text { higher education institution }\end{array}$ & $\mathrm{K}_{3}^{1}$ & & \\
\hline Total & $\mathrm{K}^{1}$ & & \\
\hline
\end{tabular}

Source: developed by the authors 
Indicators for assessing the educational and methodological support for higher education institution from the standpoint of economic security are given in table. 2 .

Table 2. Indicators for assessing the educational and methodological support of higher educational institutions from the standpoint of economic security

\begin{tabular}{|l|c|c|c|}
\hline \multicolumn{1}{|c|}{ Indicators } & Marking & True (1) & False (0) \\
\hline $\begin{array}{l}\text { Curricula for higher education are developed } \\
\text { and approved in the prescribed manner }\end{array}$ & $\mathrm{K}^{2}{ }_{1}$ & & \\
\hline $\begin{array}{l}\text { Teaching methods courses are constantly } \\
\text { updated and available for students }\end{array}$ & $\mathrm{K}^{2}{ }^{2}$ & & \\
\hline $\begin{array}{l}\text { Electronic educational and methodical } \\
\text { complexes are presented in MOODLE and are } \\
\text { used by students }\end{array}$ & $\mathrm{K}^{2}{ }_{3}$ & & \\
\hline Summary & $\mathrm{K}^{2}$ & & \\
\hline
\end{tabular}

Source: developed by the authors

Performance evaluation of scientific provision of higher education institution from the standpoint of economic security is listed in the table. 3.

Table 3. Performance evaluation of scientific provision of higher education institution from the standpoint of economic security

\begin{tabular}{|l|c|c|c|}
\hline \multicolumn{1}{|c|}{ Indicators } & Marking & True (1) & False (0) \\
\hline $\begin{array}{l}\text { Plans of scientific activities developed and } \\
\text { approved in due course }\end{array}$ & $\mathrm{K}^{3}{ }_{1}$ & & \\
\hline Students are involved in research work & $\mathrm{K}^{3}{ }_{2}$ & & \\
\hline $\begin{array}{l}\text { Research and teaching staff have academic } \\
\text { profiles in Google Scholar, ORCID, } \\
\text { ResearcherID, Scopus and actively use them }\end{array}$ & $\mathrm{K}^{3}{ }_{3}$ & & \\
\hline Summary & $\mathrm{K}^{3}$ & & \\
\hline
\end{tabular}

Source: developed by the authors

Performance evaluation of logistics of higher education institution from the standpoint of economic security are given in the Table. 4.

Table 4. Performance evaluation of logistics of higher education institution from the standpoint of economic security

\begin{tabular}{|l|c|c|c|}
\hline \multicolumn{1}{|c|}{ Indicators } & Marking & True (1) & False (0) \\
\hline $\begin{array}{l}\text { The state of logistics meets the licensing } \\
\text { requirements }\end{array}$ & $\mathrm{K}^{4}{ }^{4}$ & & \\
\hline $\begin{array}{l}\text { State of depreciation of higher education } \\
\text { institution does not exceed 50\% }\end{array}$ & $\mathrm{K}^{4}$ & & \\
\hline $\begin{array}{l}\text { Higher education institution annually renews } \\
\text { and modernizes fixed assets }\end{array}$ & $\mathrm{K}^{4}{ }_{3}$ & & \\
\hline Summary & $\mathrm{K}^{4}$ & & \\
\hline
\end{tabular}

Source: developed by the authors 
Performance evaluation information provision of higher education institution from the standpoint of economic security are given in the Table. 5 .

Table 5. Performance evaluation of information provision of higher education institution from the standpoint of economic security

\begin{tabular}{|l|c|l|l|}
\hline \multicolumn{1}{|c|}{ Indicators } & Marking & True (1) & False (0) \\
\hline $\begin{array}{l}\text { The state of information support meets the } \\
\text { licensing requirements }\end{array}$ & $\mathrm{K}^{5}{ }_{1}$ & & \\
\hline $\begin{array}{l}\text { Appropriate level of information security is } \\
\text { provided in higher education institution }\end{array}$ & $\mathrm{K}^{5}{ }_{2}$ & & \\
\hline $\begin{array}{l}\text { Provision of educational services has adequate } \\
\text { transparency }\end{array}$ & $\mathrm{K}^{5}{ }_{3}$ & & \\
\hline Summary & $\mathrm{K}^{5}$ & & \\
\hline
\end{tabular}

Source: developed by the authors

Performance evaluation of organizational and management provision of higher educational institution from the standpoint of economic security listed in the table. 6 .

Table 6. Performance evaluation of organizational and management provision of higher educational institution from the standpoint of economic security

\begin{tabular}{|l|c|c|c|}
\hline \multicolumn{1}{|c|}{ Indicators } & Marking & True (1) & False (0) \\
\hline $\begin{array}{l}\text { The activity in all areas of higher education } \\
\text { institution is regulated by the relevant internal } \\
\text { documents that comply with current legislation }\end{array}$ & $\mathrm{K}^{6}{ }_{1}$ & & \\
\hline $\begin{array}{l}\text { There are structural subdivisions in the } \\
\text { management structure of higher education } \\
\text { institution that are responsible for ensuring } \\
\text { economic security }\end{array}$ & $\mathrm{K}^{6}{ }^{6}$ & & \\
\hline $\begin{array}{l}\text { There are structural subdivisions in the } \\
\text { management structure of higher education } \\
\text { institution that are responsible for ensuring the } \\
\text { quality of educational services }\end{array}$ & $\mathrm{K}^{6}{ }_{3}$ & & \\
\hline Summary & $\mathrm{K}^{6}$ & & \\
\hline
\end{tabular}

Source: developed by the authors

Performance evaluation of higher education institution's financial security from the standpoint of economic security listed in the table. 7. 
Table 7. Performance evaluation of higher education institution's financial security from the standpoint of economic security

\begin{tabular}{|l|c|c|c|}
\hline \multicolumn{1}{|c|}{ Indicators } & Marking & True (1) & False (0) \\
\hline $\begin{array}{l}\text { The financial condition of higher education } \\
\text { institution is annually confirmed by the } \\
\text { conclusion of an independent audit service }\end{array}$ & $\mathrm{K}^{7}$ & & \\
\hline $\begin{array}{l}\text { Higher education institution's financial results } \\
\text { are published on the site }\end{array}$ & $\mathrm{K}^{7}{ }_{2}$ & & \\
\hline $\begin{array}{l}\text { Higher education institution raises funds for its } \\
\text { activities in the form of grants }\end{array}$ & $\mathrm{K}_{3}^{7}$ & & \\
\hline Summary & $\mathrm{K}^{7}$ & & \\
\hline
\end{tabular}

Source: developed by the author

Performance evaluation of administrative provision of higher education institution from the standpoint of economic security listed in the table. 8 .

Table 8. Performance evaluation of administrative provision of higher education institution from the standpoint of economic security

\begin{tabular}{|l|c|c|c|}
\hline \multicolumn{1}{|c|}{ Indicators } & Marking & True (1) & False (0) \\
\hline $\begin{array}{l}\text { Entrants of all levels are provided with bases for } \\
\text { practical training based on concluded } \\
\text { agreements }\end{array}$ & $\mathrm{K}^{8}{ }_{1}$ & & \\
\hline $\begin{array}{l}\text { Employers have positive reviews about } \\
\text { graduates }\end{array}$ & $\mathrm{K}^{8}{ }_{2}$ & & \\
\hline $\begin{array}{l}\text { The structure provides higher education } \\
\text { institution position of lobbyist for interaction } \\
\text { with public authorities, businesses and public }\end{array}$ & $\mathrm{K}^{8}{ }_{3}$ & & \\
\hline Summary & $\mathrm{K}^{8}$ & & \\
\hline
\end{tabular}

Source: developed by the author

Performance evaluation of corporate provision of higher education institution from the standpoint of economic security listed in the table. 9.

Table 9. Performance evaluation of corporate provision of higher education institution from the standpoint of economic security

\begin{tabular}{|c|c|c|c|}
\hline Indicators & Marking & True (1) & False (0) \\
\hline $\begin{array}{l}\text { Higher education institution has a long tradition } \\
\text { of providing educational services and holding } \\
\text { cultural events }\end{array}$ & $\mathrm{K}^{9}{ }_{1}$ & & \\
\hline $\begin{array}{l}\text { There is a mechanism for resolving issues of } \\
\text { violation of academic dishonesty in the activities } \\
\text { of higher education institution }\end{array}$ & $\mathrm{K}_{2}^{9}$ & & \\
\hline $\begin{array}{l}\text { Scientific, scientific-pedagogical, and other } \\
\text { employees support the norms of higher } \\
\text { education institution's corporate culture }\end{array}$ & $\mathrm{K}_{3}^{9}$ & & \\
\hline Summary & $\mathrm{K}^{9}$ & & \\
\hline
\end{tabular}

Source: developed by the author 
Performance evaluation of higher education institution's economic security state are shown in Table. 10.

Table 10. Performance evaluation of higher education institution's economic security state

\begin{tabular}{|l|c|c|c|}
\hline \multicolumn{1}{|c|}{ Indicators } & Marking & True (1) & False (0) \\
\hline $\begin{array}{l}\text { Ensuring economic security is provided in the } \\
\text { internal documents of the higher education } \\
\text { institution, including employment contracts }\end{array}$ & $\mathrm{K}^{10}{ }_{1}$ & & \\
\hline $\begin{array}{l}\text { Providing educational services, the observance } \\
\text { of the quality of the provision of educational } \\
\text { services and the economic security of higher } \\
\text { education institution are monitored }\end{array}$ & $\mathrm{K}^{10}{ }_{2}$ & & \\
\hline $\begin{array}{l}\text { Based on the results of violation of the norms of } \\
\text { quality assurance in the provision of educational } \\
\text { services and economic security, appropriate } \\
\text { management decisions are made }\end{array}$ & $\mathrm{K}^{10}{ }_{3}$ & & \\
\hline Summary & $\mathrm{K}^{10}$ & & \\
\hline
\end{tabular}

Source: developed by the author

Performance evaluation of innovative provision of higher education institution from the standpoint of economic safety are given in the Table. 11.

\section{Table 11. Performance evaluation of innovative provision of higher education} institution ZVO from the standpoint of economic security

\begin{tabular}{|l|c|c|c|}
\hline \multicolumn{1}{|c|}{ Indicators } & Marking & True (1) & False (0) \\
\hline $\begin{array}{l}\text { The service for quality assurance in the } \\
\text { provision of educational services evaluates the } \\
\text { prospects for the development of the higher } \\
\text { education market, based on the results of which } \\
\text { appropriate management decisions are made and } \\
\text { development plans are formed. }\end{array}$ & $\mathrm{K}^{11}{ }_{1}$ & & \\
\hline $\begin{array}{l}\text { Most specialties of higher education institution } \\
\text { meet the requirements of dual education }\end{array}$ & $\mathrm{K}^{11}{ }_{2}$ & & \\
\hline $\begin{array}{l}\text { Scientific and scientific-pedagogical workers of } \\
\text { higher education institution together with } \\
\text { students create new developments, drawing up } \\
\text { patents and copyright certificates for them. }\end{array}$ & $\mathrm{K}^{11}{ }_{3}$ & & \\
\hline Summary & $\mathrm{K}^{11}$ & & \\
\hline
\end{tabular}

Source: developed by the author

According to the results of an expert survey of management, scientific and pedagogical and other employees of higher education institutions, representatives of public authorities and public organizations, each of the above indicators (Annex C) was assigned a share depending on its impact on the overall economic security of higher education institution (Table 12). 
At the fifth stage, the formation of an integrated indicator for assessing the state of comprehensive economic security of higher education institution and its characteristics is made. We propose to calculate the integrated indicator according to the formula:

$$
\mathrm{K}=\sum_{\mathrm{i}=1}^{11} \Pi_{\mathrm{i}} \mathrm{K}^{\mathrm{i}}
$$

where $\mathrm{K}$ is an integrated indicator of assessing the state of comprehensive economic security of higher education institutions; $\Pi_{\mathrm{i}}$ is the proportion of each indicator; $\mathrm{K}_{\mathrm{i}}$ are indicators for assessing the state of comprehensive economic security of higher education institutions given in table. 1-11.

\section{Table 12. The share of indicators for assessing the state of comprehensive} economic security of higher education institution

\begin{tabular}{|c|c|c|}
\hline & Name of indicator & Share \\
\hline $\mathrm{K}^{1}$ & Indicators of higher education institution's personnel evaluation & 0,15 \\
\hline $\mathrm{K}^{2}$ & $\begin{array}{l}\text { Indicators for evaluating educational and methodological } \\
\text { support of higher education institution }\end{array}$ & 0,1 \\
\hline $\mathrm{K}^{3}$ & $\begin{array}{l}\text { Performance evaluation of higher education institution's } \\
\text { scientific support }\end{array}$ & 0,1 \\
\hline $\mathrm{K}^{4}$ & Indicators of logistics assessment of higher education institution & 0,1 \\
\hline $\mathrm{K}^{5}$ & $\begin{array}{l}\text { Indicators for evaluating the information support of higher } \\
\text { education institution }\end{array}$ & 0,1 \\
\hline$K^{6}$ & $\begin{array}{l}\text { Indicators for assessing the organizational and managerial } \\
\text { support of higher education institution }\end{array}$ & 0,05 \\
\hline $\mathrm{K}^{7}$ & $\begin{array}{l}\text { Indicators for assessing the financial support of higher } \\
\text { education institution }\end{array}$ & 0,15 \\
\hline $\mathrm{K}^{8}$ & $\begin{array}{l}\text { Indicators for assessing the administrative support of higher } \\
\text { education institution }\end{array}$ & 0,05 \\
\hline $\mathrm{K}^{9}$ & $\begin{array}{l}\text { Indicators for assessing the corporate security of higher } \\
\text { education institution }\end{array}$ & 0,05 \\
\hline $\mathrm{K}^{10}$ & $\begin{array}{l}\text { Indicators for assessing the state of economic security of higher } \\
\text { education institution }\end{array}$ & 0,1 \\
\hline $\mathrm{K}^{11}$ & $\begin{array}{l}\text { Indicators for assessing the innovative provision of higher } \\
\text { education institution }\end{array}$ & 0,05 \\
\hline K & $\begin{array}{l}\text { An integrated indicator for assessing the state of comprehensive } \\
\text { economic security of higher education institutions }\end{array}$ & 1,0 \\
\hline
\end{tabular}

Source: developed by the author

Obtained result will characterize the compliance to standards of the state of complex economic security of higher education institution according to the criteria given in table. 13 . 
At the sixth stage the analysis of interaction of complex maintenance of economic safety of higher education institution with internal and external environment on the basis of a technique of an estimation of economic safety of an institution of higher education is carried out.

Table 13. Criteria for compliance with the standards of the state comprehensive economic security of higher education institutions

\begin{tabular}{|c|l|c|}
\hline Rank & \multicolumn{1}{|c|}{ Characteristic } & Points \\
\hline A & $\begin{array}{l}\text { The state of comprehensive economic security of higher education institutions } \\
\text { fully complies with the established standards }\end{array}$ & $2,56-3,0$ \\
\hline Б & $\begin{array}{l}\text { The state of comprehensive economic security of higher education institutions } \\
\text { meets the established standards, but there are tendencies to its deterioration }\end{array}$ & $2,1-2,55$ \\
\hline В & $\begin{array}{l}\text { The state of comprehensive economic security of higher education institution } \\
\text { meets the established standards, but there are certain shortcomings that were } \\
\text { eliminated during the internal monitoring }\end{array}$ & $1,51-2,0$ \\
\hline$\Gamma$ & $\begin{array}{l}\text { The state of comprehensive economic security of higher education institutions } \\
\text { meets the established standards, but there are certain shortcomings that were } \\
\text { eliminated during the external state or departmental control }\end{array}$ & $0,06-0,15$ \\
\hline Д & $\begin{array}{l}\text { The state of comprehensive economic security of higher education institutions } \\
\text { does not meet the established standards }\end{array}$ & $>0,05$ \\
\hline
\end{tabular}

Source: developed by the author

We offer to analyze the interaction of integrated economic security of higher education institution with the internal and external environment in the following sequence (Fig. 3).

We believe that the results of assessing the state of comprehensive economic security of higher education institutions should be carried out:

1) By higher education institution security service together with the educational quality assurance service and use it for:

- preparation for self-analysis at the beginning and end of academic year;

- submission of proposals for the development of higher education institution strategy for next five years;

2) By public authorities and administration to decide on the provision of budget funds for the development of higher education institution;

3) By independent public organizations to form an independent public opinion on the quality of educational services to higher education seekers.

Therefore, the proposed methodological approach to assessing the state of integrated economic security of higher education institutions is universal for all higher education institutions, both private and state or communal, and can be used in practice. 
Planning and preparation for evaluation

- goal setting

- decision-making on the assessment

- formation of an evaluation group

- development of evaluation schedule and search for resources

- choice of techniques and methods of work

- selection of initial data and staff training

- selection of specific assessment objects

Evaluation

- evaluation of individual scientific and pedagogical workers;

- evaluation of project groups / specialty support groups

- evaluation of individual structural units

- evaluation of free economic zones in general

Obtaining evaluation results

- selection and processing of information

- detection of threats, description of a dangerous situation, identification of employees exposed to the threat

- assessment of the significance of the threat, the probability of its occurrence, the formation of a matrix of threats

- choice of measures to respond to threats

Fig. 3. Areas of analysis of the interaction of integrated economic security of higher education institution with internal and external environment

Source: developed by the author

\section{References:}

1. Hreben S., Mihus I., Parashchenko L., Laptiev S. and Alkema V. (2019), The mechanism of financial control over the allocation of budgetary funds depending on the results of scientific activity of a higher education institution. Finansovo-kredytna diialnist: problemy teorii ta praktyky, №4(31), pp. 466-476. DOI: http://dx.doi.org/10.18371/fcaptp.v4i31.190998.

2. Mihus Iryna \& others (2012). Modern prospects for the development of economic security systems of the state and economic entities: a monograph. $636 \mathrm{p}$.

3. Laptev S., Zakharov O. and others (2010) Management of financial and economic security: a monogaph. $480 \mathrm{p}$. 